\title{
Investigation of the spatial and temporal trends of the air temperature of the Hajnóczy cave in the Bükk mountains
}

\author{
Muladi BeátaA*, Mucsi LászlóA \\ Received: June 18, 2014 | Revised: July 20, 2014 | Accepted: August 24, 2014
}

\begin{abstract}
The aim of this study is to measure and analyze the effects of exterior annual temperature change on the interior temperature of a dripstone cave. The measurement was carried out in Hajnóczy Cave located in the southern part of the Bükk Mountains, Hungary.

Although the cave has only one entrance known, there are more evidences that prove the strong effect of exterior conditions on the interior processes like temperature fluctuation and dripstone development. Using a high resolution wireless digital thermometer sensor network, the air temperature was measured at 10 points every 10 minutes for a longer period. The goal of our study is to analyze the spatial profile of air temperature of the cave that is developed during the summer and winter air circulation period between 11 November, 2012, and 10 April, 2013. Based on these data, different zones of the cave could be separated; and during the winter and summer conditions, the climatic variability of the entrance, the transitional, and the deep cave zone were described. The long-term analysis of the cave proved that the summer and winter air circulation changes are caused by the prolonged continuance of a below $10^{\circ} \mathrm{C}$ average daily temperature.
\end{abstract}

Key words: Cave temperature, wireless sensor network, Hajnóczy Cave, Hungary

\section{Introduction}

Global climatic changes can also influence the under cave climate. It is proven that mountain thermal inertia causes a delay between the two climates, which then results in a thermal unbalance between the cave atmosphere and the surface atmosphere (Badino, 2004). High resolution microclimate studies can give very useful spatial information about the air mass movement not only in the show caves but in such caves which are visited and investigated only by researchers (Cigna, 2002). Based on their environmental conditions and environmental variability, cave habitats can be divided into three primary zones: 1) an entrance area that is climatically variable and strongly affected by changes in the surface environment, 2) a deep cave zone that is characterized by relatively stable temperature, and humidity at or near saturation, and 3) a transition zone that seasonally displays characteristics of either the entrance or the deep cave zone. The spatial extents of these zones vary among caves and are primarily determined by passage morphology and airflow patterns (Benjamin, et. al., 2013). All caves are different concerning their morphology, fracture network as well as their entrance position; all these exert influence on their air flow (Rajczy, 2000).

Hungary has a great variety of karstic landscapes. Kessler, H. and Jakucs, L. started the academic investigation of the surface and underground karstic features in the middle of the $20^{\text {th }}$ century. All caves enjoy ex lege protection (LIII/1996 Act on the Protection of the Natural Environment), moreover, the protection of some of the larger karstic landscapes is maintained by national parks (e.g. Bükk Mts., Aggtelek Karst), in

\footnotetext{
A Department of Physical Geography and Geoinformatics, University of Szeged, Egyetem u. 2-6, H-6722 Szeged, Hungary

* Corresponding author: Muladi Beáta,e-mail: muladi@geo.u-szeged.hu
} 
addition, the caves of Aggtelek Karst and Buda Karst are even parts of the UNESCO World Heritage.

The most significant results of the Hungarian karstic and cave researches are as follows: the complex geomorphologic interpretation of karstic landscapes (Jakucs, 1977; Hevesi, 2002), the study of thermal karstic regions (Leél-Őssy, Surányi, 2004), the investigation of the soil effect (Zámbó, 1993; Bárány-Kevei, Mucsi, 1995), the study of the annual change of the radon concentration in caves (Somogyi, et al. 1983; Hakl, et al., 1997), the analyses of the therapeutic caves (Horváth, 1984), the analysis of cave climate (Fodor, 1980), and the morphometric characterization of cold karts (Veress, 2009).

Efforts were made to carry out long-term analysis of karstic processes and phenomena in the 1980s and 1990s. Zámbó L. built up a vertical automatic sampling and measuring system in order to investigate the soil effect (Zámbó, 1993). Measuring subsurface processes, especially changes in cave temperature and humidity has only been possible in show and therapeutic caves, where the power supply of the devices was provided with the already installed wiring (Kaffai, Imecs, 2008).

The development of wireless sensors enabled speleologists to carry out researches in protected caves where only researchers were admitted before (Muladi, et al., 2013). These sensors have their own power supply which enables them to operate on for months and record a range of different data such as cave air temperature, relative humidity or air pressure.

Hajnóczy Cave is a large dripstone cave located in the Bükk National Park, and since its discovery in 1971, continuous exploring has been going on parallel with lots of academic research and measurement (Varga, 1970; Varga, 1978; Németh 1964; Miklós, Városi, 1978; Mucsi 1992).

The goal of our study was to analyze the quantitative relationship of the surface temperature and that of the cave with the help of a wireless sensor network using the data of a longer measurement period (preferably 1 year at least), which is based on large-scale (10-minute) data records. After gathering previous data, and investigating easily observable phenomena, we focused on studying to what extent surface climate affects the air temperature and the direction of the air flow in cave passages of different cross-section. By analyzing the one-year long data records, we also wanted to find out what surface temperature causes changes in the direction of cave air flow. Based on our measurement data, we mapped the horizontal and vertical temperature distribution of the cave air, and analyzed the possible causes of the differences.

\section{Study area}

Hajnóczy Cave is located in the south-western part of the Bükk Mountains. The cave entrance can be found on the Odorvár hill slope $475 \mathrm{~m}$ above sea level. Odorvár $(574 \mathrm{~m})$ is a limestone hill situated in the western side of the valley of the Hór creek. The "odor" word means "area with hollows". The total length of its corridors is ca. $4257 \mathrm{~m}$, the vertical difference between the highest and deepest points is $125 \mathrm{~m}$.

The cave was formed in Ladinian and Karnian cherty grey limestone. Another significant surface rock is the older clay slate (Odor Mt., $661 \mathrm{~m}$ a.s.1.). The limestone and the clay slate were significantly folded as a result of Cretaceous tectonic movements; the older clay slate was folded on the younger limestone (Hevesi, 1978). Important deformation events occurred as a result of the Austrian mountain formation processes (folding, overthrust folding, fault deformation), and then these processes were followed by continental erosion in the Paleogene, which is proven by the geochemical investigation of cave sediments very well (Mucsi, 1992). The region was exposed to continental erosion for a longer period in the Upper Eocene and Lower Oligocene than it was exposed to marine sedimentation. The surrounding area of Odor Mt. and Odorvár was exposed to periodical marine transgression, then after the regression of the sea the area was massively exposed to continental erosion again. A part of the caves (Entrance and Giant Hall) was formed by mixture corrosion, while the cave parts located in the limestone beneath the overlying clay slate (Grand Canyon, Tsitsogó) were also greatly formed by tectonic preformation (detached bedding planes). The Quaternary development of the region is not so wellknown; however due to the sinking karst water level occurring in the Pleistocene, the multi-level cave system formed earlier also became dry. According to the investigations of Hir (1985), Hajnóczy Cave is one of the oldest caves of the Bükk Mountains (Figure 1).

The greater part of Hajnóczy Cave is near the surface. The Giant Hall is situated the closest to the surface, reddish-colored tree roots can be observed in the ceiling of the hall (Mucsi et al., 2004). Giant Hall is situated near the peak of Odor Mt., where the rendzina type soil under the karst scrub forest warms up more easily the due to the southern exposure. This part of the karst is of autogenic nature (dripping water comes only from precipitation) (Jakucs, 1977), and the catchment area of the cave is rather small. As the overlying rock of the hall, which is also situated near the top of the mountain, rainwater filters into the cave quickly. The greater halls of cave were formed with mixture corrosion below karst water level. The incision of the Hór Creek induced the sinking of karst water level, therefore the halls dried 


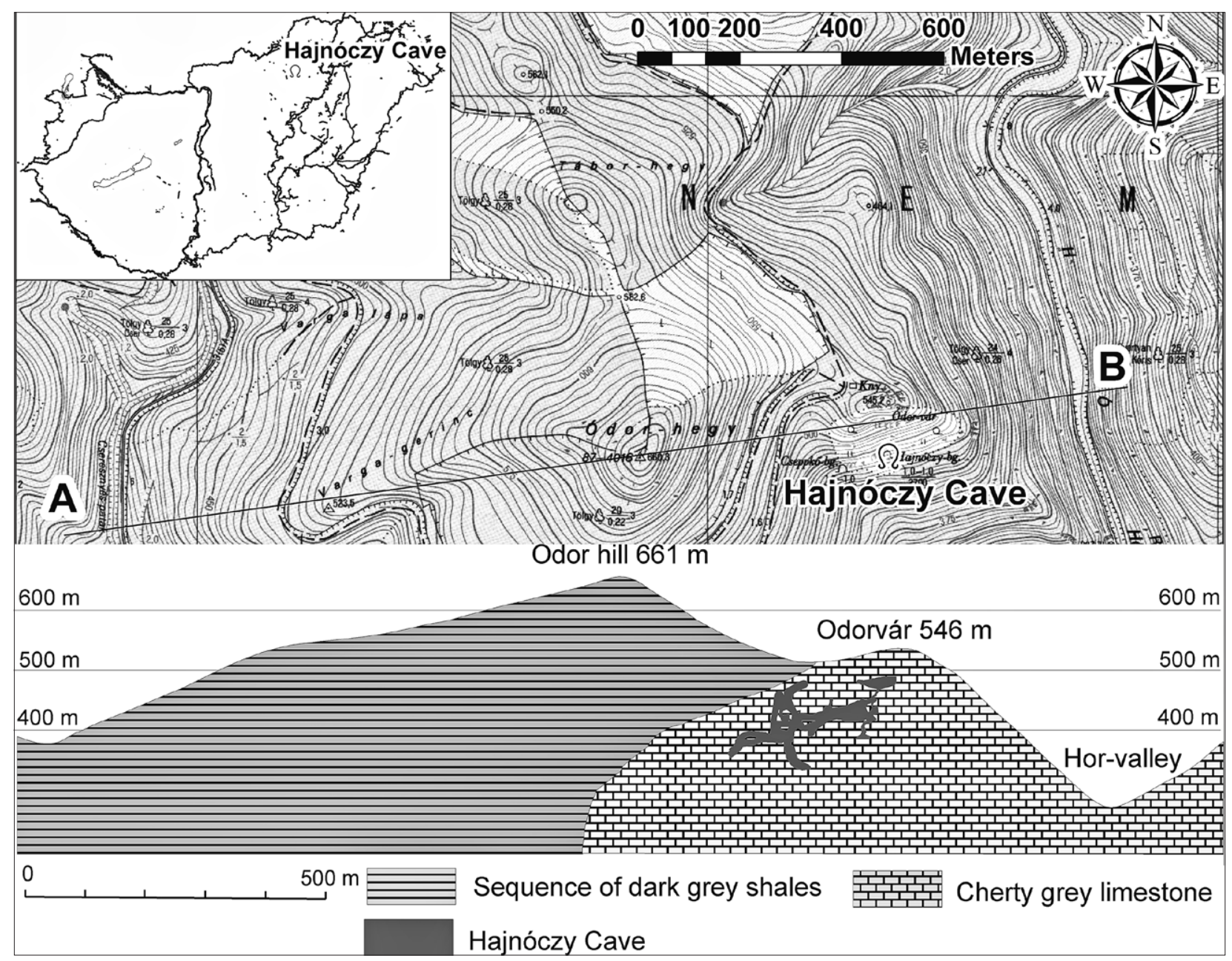

Figure 1. Geological structure of Odorvár and Odor Mt. with the cross-section of Hajnóczy Cave (WSW-ENE direction) Edited by Muladi B., based on Mucsi L. (1989)

up, and dripstone formation began due to the presence of dripping water. The varying amount of precipitation is indicated by the presence of a large dripstone flow on the eastern limestone surface of the Great Hall, which was formed in the earlier wetter periods (Varga, 2003). Dripping and dripstone formation are only present after rainy days nowadays, the Great Hall is the driest part of the cave anyway. Relative humidity significantly decreases in extremely dry periods, the surface of the dripstones dries up as a result, and the degradation of the dripstones starts.

The climate of the cave is of statodinamic nature because cave air flows outside into the open air through the whole cross section of the cave opening in summer (Fodor, 1981).

Hajnóczy Cave was discovered in 1971, and its mapping and scientific investigation started immediately after its discovery. The first air temperature measurement series were executed by Miklós, G. and Városi, J. from 1975 to 1977 . According to their measurements the air temperature ranged from $8.5^{\circ} \mathrm{C}$ to $10.5^{\circ} \mathrm{C}$. The relative humidity then was higher than $98 \%$ on average, but there were wetter and drier halls in the cave.
Based on continuous observations it can be stated that the halls near to the surface are drier, while the halls and the corridors deep under the surface are wetter. It was also proven that if the difference between the cave and the surface air temperature is about $10^{\circ} \mathrm{C}$, the amount of the moving air is ca. $0.4 \mathrm{~m}^{3} / \mathrm{s}$. Air velocity ranges from 5 to $25 \mathrm{~cm} / \mathrm{s}$, at the entrance part it was $20-40 \mathrm{~cm} / \mathrm{s}$, while the air flow impulsion reached 50 $\mathrm{cm} / \mathrm{s}$ (Miklós, Városi, 1978).

The force of the air circulation and the direction change of the seasonal air circulation affect the radon concentration of the air as well. Analyzing the soil gas activity of Hajnóczy Cave its maximum was measured in July, and its minimum in the winter-spring months (Somogyi, et al., 1983), when the air flows outside sweeping through the crevice network and the bigger halls toward and through the only known entrance. The alpha-activity level of the air was higher everywhere than that of the soil gas, but its volume was also greatly determined by air temperature and air flow (Kordos, 1984). The values of microclimatic parameters are also influenced by the fact that the natural entrance of the cave is blocked by an iron 


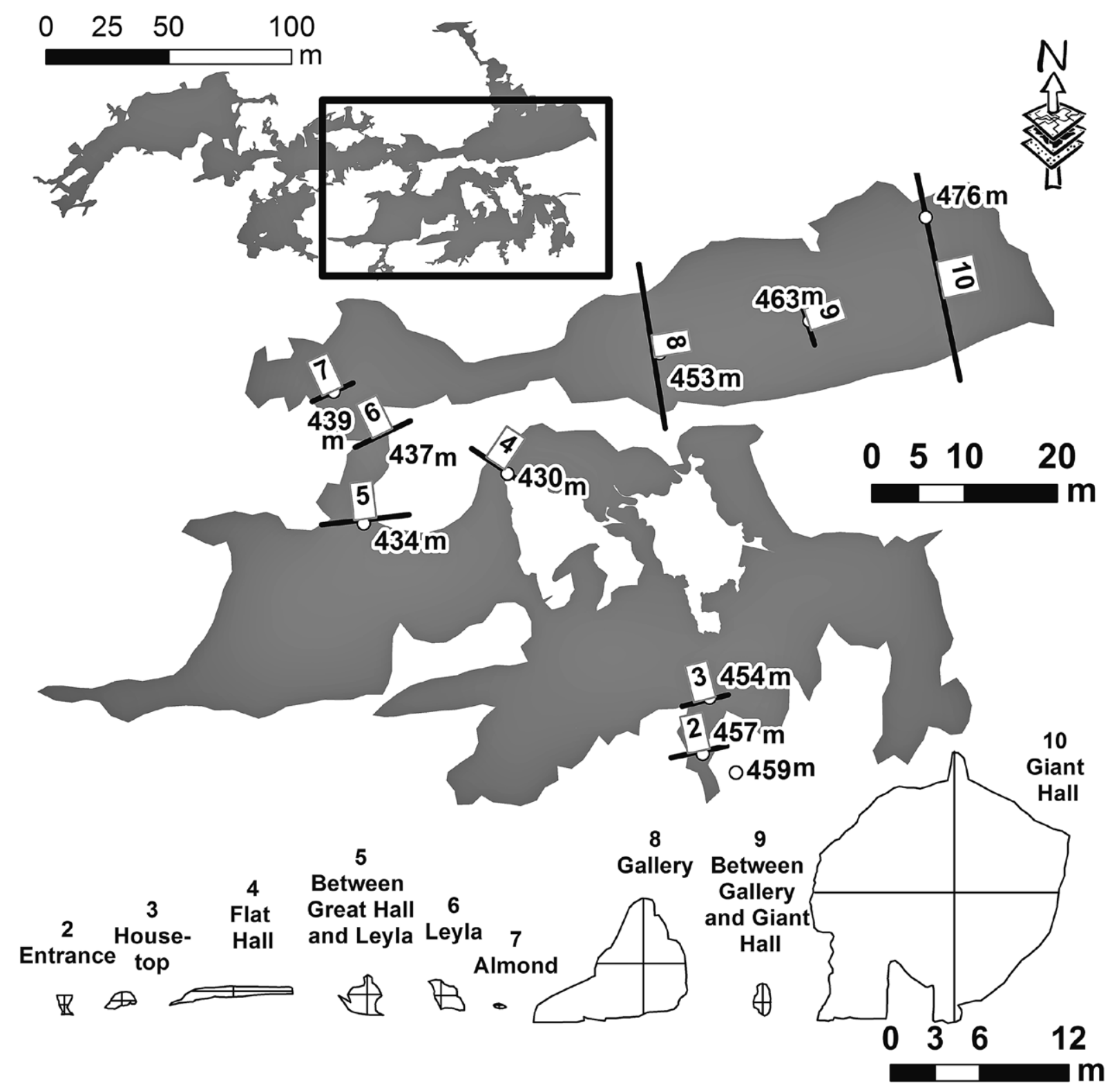

Figure 2. Horizontal plan of Cave Hajnóczi indicating the a.s.l. height and cross section of the research points Drawn by Muladi, $B$. based on previous cave maps

door throughout the year. This iron door has a small opening on it for bats to fly through, and the air flows through this so-called "bat-openings" only. The previously mentioned influence of the door was measured in the course of a short-term radon analysis. During this period only a minimal change of the radon level was observable in the entrance part too (Dezső, 2001).

\section{Data and methods}

The air temperature measurement was carried out in the two morphologically distinguishable parts of the cave.

The first investigated area was the entrance part of the cave, which can be characterized by narrow corri- dors. After this part the cave halls were formed along bedding planes by karstic corrosion. This kind of passage system, which is rich in narrow corridors, continues from the cave entrance through The Housetop and the Ruin Hall to the Great Hall. This part can be described as a labyrinth, in which the distance between the bottom and the ceiling of the halls continuously increases.

Further parts of the cave can rather be described partly as large halls formed by erosive processes and by small and narrow corridors which connect these halls. This section contains Leyla (6), and a very narrow passage called the Almond (7), which is named after its cross sectional shape. The Almond passage is followed by the Gallery (8) with 10-15 $\mathrm{m}$ high hall. This 
is one of the most beautiful halls of the cave because of numerous stalagmites it exhibits. The largest hall of the cave is called as the Giant Hall (10), which is the last hall on the west-eastern part of the cave. The horizontal dimension of this hall is $62 \times 16 \mathrm{~m}$, while its vertical dimension is 10-12 $\mathrm{m}$ (Figure 2).

Present research activity started in December, 2011. Three months were needed to test how to operate the instruments in the cave. Almost 2 years of continuous measurements have resulted in detailed information about the annual trend of the cave air temperature and the main features of the cooling and warming processes (Muladi et al., 2013). The aim of our study was to determine the spatial profile of the air temperature of the cave developed during the summer and the winter air circulation period between 11 March 2012 and 10 April 2013. Horizontal air movement as well as vertical lamination could be identified because all necessary digital equipment was installed in different halls and corridors of the cave at the same time. Air humidity was also measured besides the air temperature.

The UC Mote Mini low power wireless sensor module developed at the University of Szeged was used for our measurements (Figure 3). Each device has a SHT21 sensor, which can measure temperature with an accuracy of $\pm 0.3^{\circ} \mathrm{C}$, and $0.01^{\circ} \mathrm{C}$ resolution. Data collection can be realized with $2 \mathrm{MB}$ external flash TinyOS, which is a small open-source energy-efficient software operating system, supporting large scale selfconfiguring sensor networks. The device is powered by LIR2450 battery (Mucsi et al., 2014). During our study, data were recorded every 10 minutes. The sensors could be used for more than 3 months without battery replacement.

The temperature and relative humidity of the cave air were detected using 10 sensors (3 of which could also measure air pressure) in Cave Hajnóczy. In each case, one of the sensors was placed near the cave entrance to measure surface temperature (Figure 2.).We had weather data from the meteorological station in Eger. These temperature data were used to supplement our data from the sensors placed on the surface (Ogimet). The data analysis of the daily average of the 10-minute data set was used.

We employed cokriging in the spatial analysis, and we studied the distribution of the temperature data in the vertical dimension of the cave, where the height data of the mapping points were used.

We hypothesized that in the process of cokriging there is correlation between the parameter to be estimated and another parameter having more wellknown statistical characteristics. By using these two data sets, in areas where information needed to interpolate the parameter to be estimated is missing, the es-

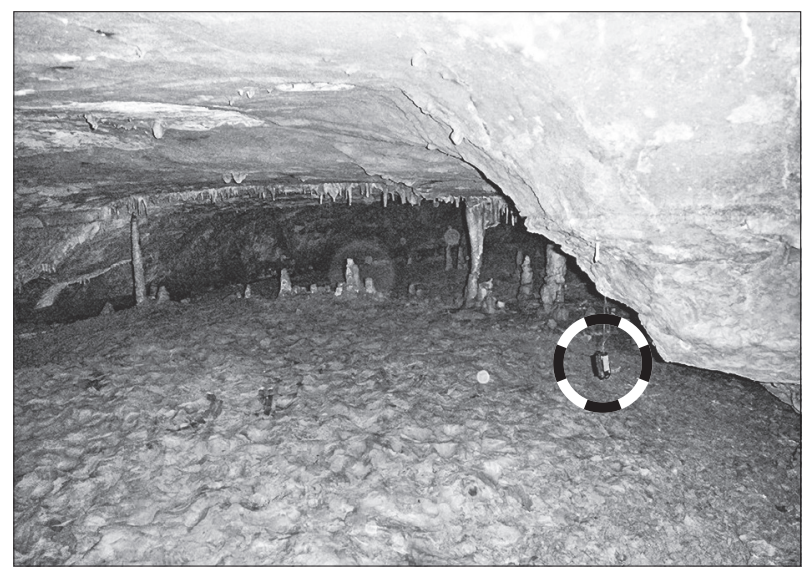

Figure 3. UC Mote Mini in the Flat Hall (Photo: Muladi B.)

timation of the parameter sought after can be done by employing cross-correlational calculation on the basis of the second data set (Aboufirassi, Marino, 1984).

We used anisotropy when the method of cokriging was employed. Anisotropy means a certain property of the spatial process or data where spatial dependence (autocorrelation) changes with both the distance and the direction between two locations (Johnston et al., 2003).

Thermal distribution can be analyzed by visualizing the spatial trend of temperature in the projections of a 3-dimensional system of co-ordinates. The values of the $\mathrm{z}$-axis represent temperature, the zy-axis represents the east-west directional temperature distribution, while the zx-axis represents the northsouth directional distribution. When visualizing the spatial trend, a polynom of the second- degree is adjusted to the date on the projections. The polynom of the second degree can be denoted in the equation $y=a x^{2}+b x+c$, where a upward curve can be found if $a>0$, and a downward curve if $a<0$.

When visualizing data, surface temperature data were also used for generating the polynom of second degree.

\section{Results}

\section{Temperature changes in Hajnócy Cave and the surface}

In the beginning of the research we tested our instruments, then from the spring of 2012 on, we also started gathering data that could be well evaluated due to the trustworthy operation of our sensors. In July, 2012, we added 22 new sensors to the already operating 10, and they all recorded data every 10 minutes. On the basis of data of these 32 sensors, we analyzed the relationship between the surface and the cave. Based on these data, different zones of the cave could be separated, 
and, during summer weather conditions, the climatic variability of the entrance transitional and that of the deep cave zone were described. According to the statistical analysis of the spatial information, significant correlation was found between the daily fluctuation of the exterior temperature and that of a cave chamber that is relatively far from the cave entrance. This fact proves the existence of a fissure system which is permeable for air but not passable for cavers. Because of the surface distance, the effects of the environmental change may have serious impact on the cave and its natural phenomena (Muladi, Mucsi, 2014).

The two-year-long ongoing measurement series gave us the opportunity to study and analyze the annual temperature change and the seasonal direction change of air circulation in the cave.

Surface air temperature was measured by a sensor placed 2 meters high above the cave entrance. The data series it provided was supplemented with the data recorded at the nearest meteorological station in Eger (Figure 4). The temperature diagrams of the two data sets can be adjusted to each other well (their correlation coefficient is 0.95), the only difference between the two data sets is the values of the daily minimum and maximum temperatures, which differ only $1-2^{\circ} \mathrm{C}$ from each other, which is due to the a.s.l. height difference of the sensors ( $241 \mathrm{~m}$ ).

Surface data reflect seasonal changes very well. The spring period lasts from 11 March to 26 April, when temperature changes between 5 and $15^{\circ} \mathrm{C}$. It is followed by a second period, summer, when a gradually warming tendency is present with temperature changing between $12-30^{\circ} \mathrm{C}$. this period ends on 8 August. The third period brings a gradual cooling trend up to 30 November; the minimum values in this period are around $5^{\circ} \mathrm{C}$. This cooling period represents the steepest trend in the seasonal breaking down of the data. Finally, the last period brings below freezing point temperature, the temperature varies between -6 and $+5^{\circ} \mathrm{C}$. In the last days of the winter period the daily maximum temperature values rise above $5^{\circ} \mathrm{C}$ already (Figure 4 ).

The entrance of the cave (2) (Figure 1) is located on the Odorvár side of the mountain. During summer air circulation, air from the cave flows outside through the total cross section of the entrance. On the basis of the 1977 summer measurement records of Miklós, G., the average daily air circulation speed is $27.01 \mathrm{~cm} / \mathrm{s}$.

The chart (Figure 5) depicts well that the summer period is characterized by a flattened curve, which means that the air temperature is $8^{\circ} \mathrm{C}$ with a minimal $0.5^{\circ} \mathrm{C}$ change. As soon as surface temperature falls below $10^{\circ} \mathrm{C}$, the direction of the air flow changes, and it is surface temperature that influences the entrance part. The phenomenon is most observable in the spring and autumn periods when temperature changes between 6 and $8^{\circ} \mathrm{C}$ in the entrance part. The cold thick air flows down the entrance part in the winter period and induces strong temperature fluctuations ranging from -1.3 to $6^{\circ} \mathrm{C}$.
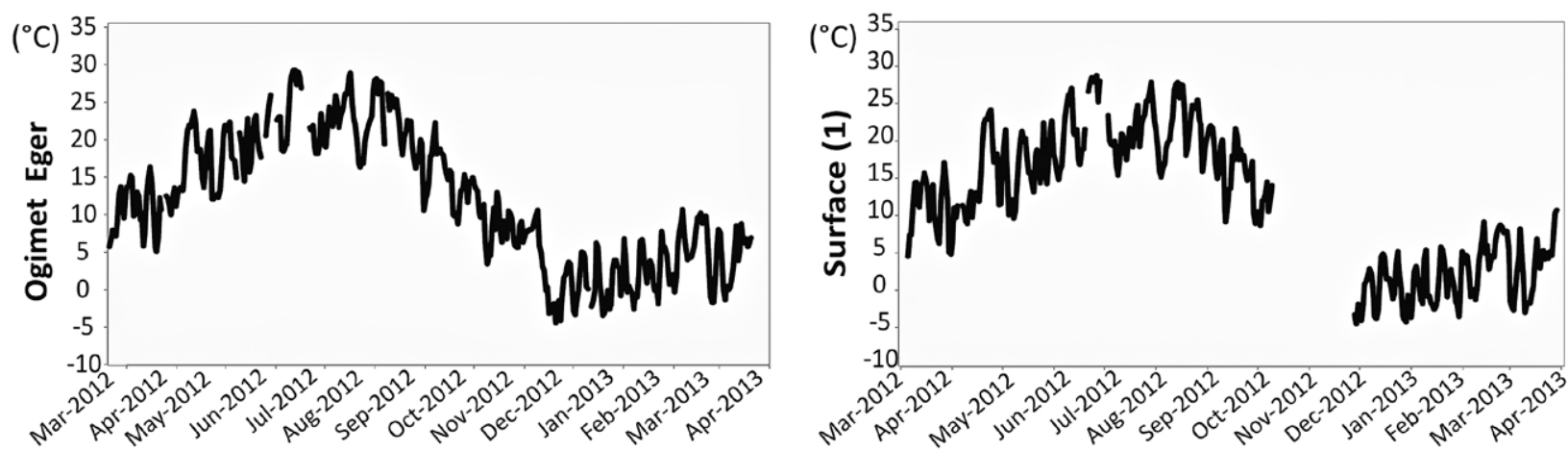

Figure 4. Surface temperature of the meteorological station in Eger and that of the cave entrance
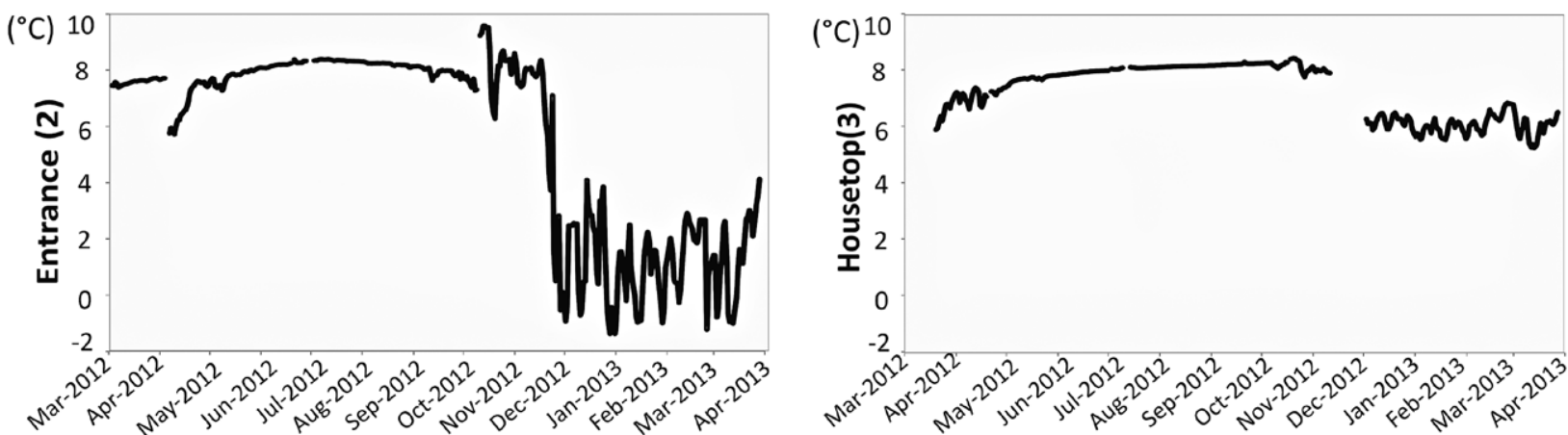

Figure 5. Temperatures recorded at the entrance part of Hajnóczy Cave and at Housetop 
The Housetop, which is vertically $14 \mathrm{~m}$ away from the entrance, exhibits the same processes only more weakly as the entrance part, temperature changes are between 5.4 and $8.6^{\circ} \mathrm{C}$ (Figure 5).

The sensor placed in the Flat Hall (4) is vertically the deepest point (430 m) (Figure 2) of the cave, and vertically it is located $47 \mathrm{~m}$ away from the entrance. Surface temperature trends are present here already, although the daily fluctuation of the temperature cannot be observed here in the summer period, but it is present in the winter period $\left(7.4-8.4^{\circ} \mathrm{C}\right)$ (Figure 6).

The next point of investigation is located between the Great Hall and Leyla (5). The Great Hall is $48 \mathrm{~m}$ long and $14 \mathrm{~m}$ wide, its height varies between 5 and $8 \mathrm{~m}$. The gradually narrowing passages of Leyla (6) and the Almond (7) can be found from here onward, and these passages lead to the Gallery (Figure 2). These three points of investigation represent almost the same temperature range, however, vertical lamination is present even in this $2-3 \mathrm{~m}$ level difference as well. The part between the Great Hall and Leyla (5) is located $434 \mathrm{~m}$ high a.s.l., its distance from the entrance is $53 \mathrm{~m}$, and temperature here varies between 8.o- $8.8^{\circ} \mathrm{C}$ (Figure 6). Leyla (6) is located $437 \mathrm{~m}$ high a.s.l., its distance from the entrance is $57 \mathrm{~m}$, and temperature here varies between $8.2-9.1^{\circ} \mathrm{C}$ (Figure 6). The Almond (7) is located $439 \mathrm{~m}$ high a.s.l., its distance from the entrance is $64 \mathrm{~m}$; temperature here is $0.1^{\circ} \mathrm{C}$ higher in the warming period than in Leyla, while in the cooling period temperature is $0.1^{\circ} \mathrm{C}$ lower than that of Leyla's (Figure 6). Temperature trends are almost the same in this gradually narrowing passage, of which cross section is gradually narrowing, winter and summer air circulations are
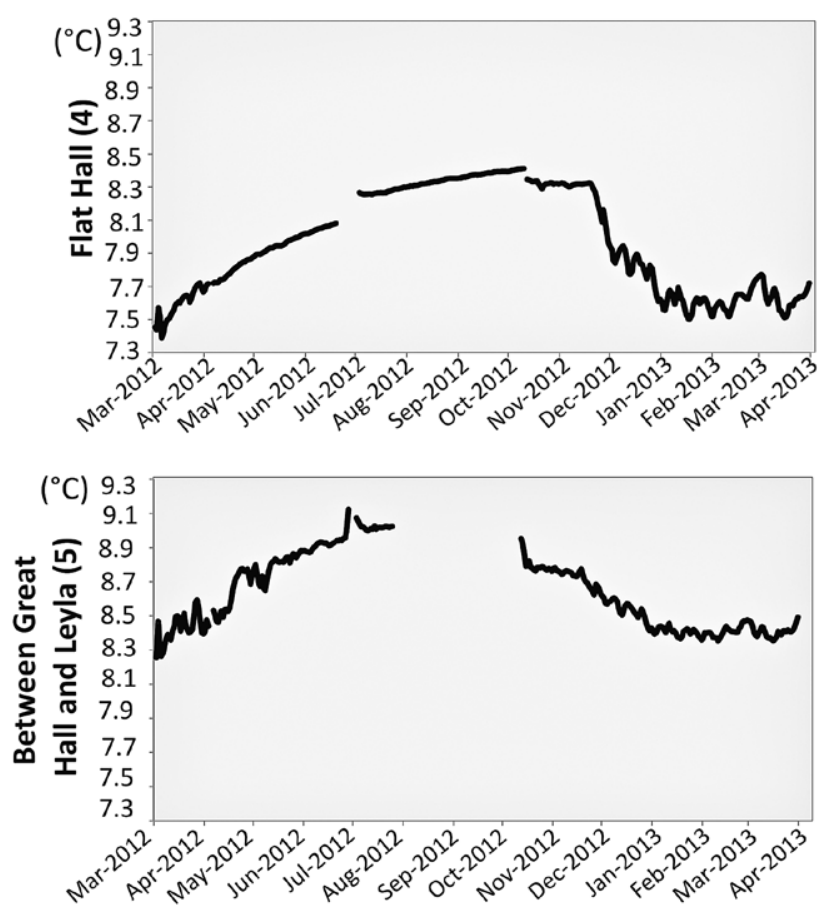

well distinguishable. Although outward air circulation is dominant in the cave in the summer period, when surface air temperature drops to $10^{\circ} \mathrm{C}$, temperature data recorded at these points of investigation are modified with $0.2^{\circ} \mathrm{C}$

The Gallery (8) is very rich in dripstone formations; it is $70 \mathrm{~m}$ long, $1-8 \mathrm{~m}$ wide, and 4-13 $\mathrm{m}$ high. The abundance of dripstones in the gallery is due to the fact that its ceiling is formed of vertical limestone plates, from which lime-bearing water was always dripping. The $63 \mathrm{~m}$ long, $14 \mathrm{~m}$ high and $16 \mathrm{~m}$ wide Giant Hall (10) (Figure 2) can be approached from the eastern end of the gallery; the path leads among huge, severalton heavy rocks collapsed into the passage a long time ago. Due to the big size of the halls and the amount of previously collapsed rocks, no strong seasonal changes can be observed at the last three points of investigation. The data also represent the spatial lamination well: the Gallery (8) is located $453 \mathrm{~m}$ high a.s.l., its distance from the entrance is $101 \mathrm{~m}$, and temperature here varies between 9.5-9.8 ${ }^{\circ} \mathrm{C}$ (Figure 7). The investigation point between the Gallery and the Giant Hall (9) is located $463 \mathrm{~m}$ high a.s.l., its distance from the entrance is $112 \mathrm{~m}$, and temperature here varies between 10.1 and $10.2^{\circ} \mathrm{C}$ (Figure 7). The Giant Hall (10) is the highest location of the cave, it is located $476 \mathrm{~m}$ high a.s.l., its distance from the entrance is $132 \mathrm{~m}$, and temperature here varies between 10.7 and $10.9^{\circ} \mathrm{C}$ (Figure 7). The seasonal and the daily changes are well depicted in the Giant Hall (10) - with minimal changes though. It is the result of the phenomenon that while the air flows out the entrance of the cave in the sum-
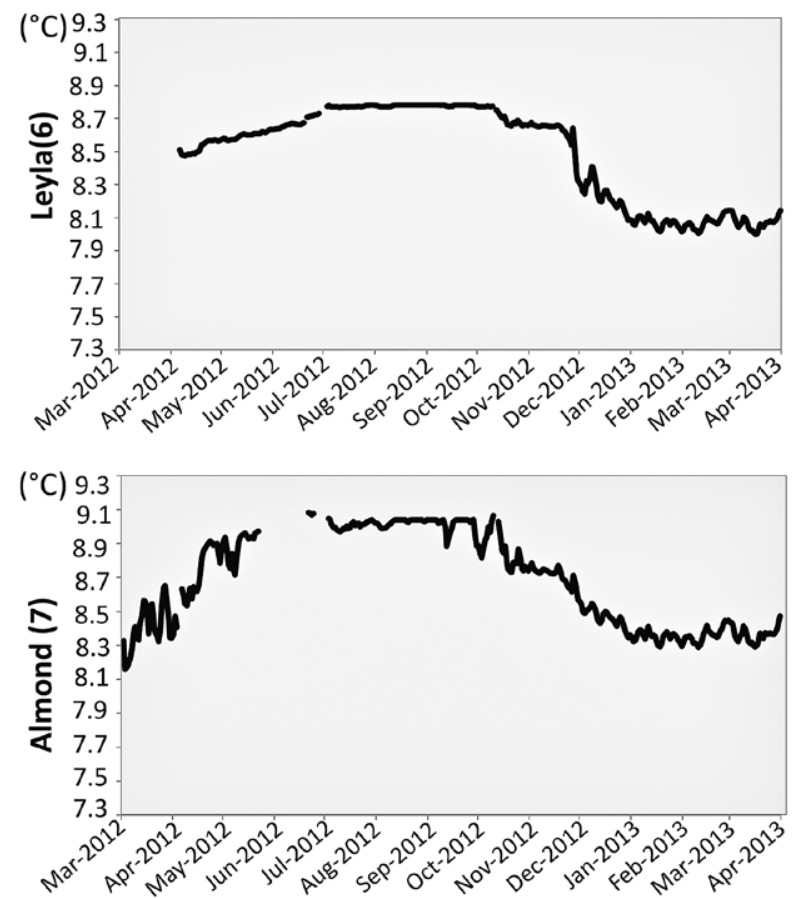

Figure 6. Temperatures recorded at the Flat Hall (4), Between Great Hall and Leyla (5), Leyla (6), Almond (7) 


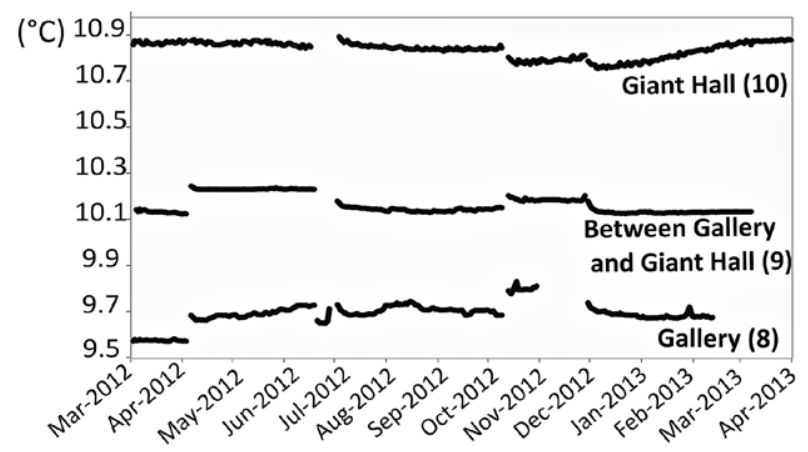

Figure 7. Temperatures recorded at the Gallery (8), between Gallery and Giant Hall (9), Giant Hall (10)

mer, the crevice network of the Giant Hall provides new supplements of air. The morphological characteristics of the Giant Hall also induce minimal changes, but the surface temperature trends appear too.

We carried out trend analysis in the total research period between 11 March 2012 and 10 April 2013. When there was no data available, that point of time was excluded from the study. In the course of the trend analysis the data series of each point of investigation shows negative trends. These trends correspond to the surface trend of the research period due to the usual air circulation of the cave. The significant level of the trend was $1 \%$ among the following points of investigations: between the Great Hall and Leyla (5), Leyla (6), the Gallery (8), between the Gallery and the Giant Hall (9), and the Giant Hall (10). These points take part in the air circulation of the cave either partly or totally, they are less influenced by the surface changes.

\section{Spatial analysis}

We employed cokriging during the spatial analysis where we studied the distribution of temperature data (9 pieces) in the vertical dimension of the cave. In or- der to do so, we used the height data of the mapping points ( 456 pieces) of the researched cave part.

In order to depict the winter and summer spatial temperature distribution of the cave, we used the cave temperature data and the height data of the polygon points in the course of cokriging interpolation. We chose two different dates: one summer (13 July 2012) and one winter (19 January 2013) date. The reason for choosing these two dates was that surface temperature was steadily over $15^{\circ} \mathrm{C}$ and below $5^{\circ} \mathrm{C}$ these months. We employed the average daily temperature values of these two days. In order to be able to compare them more, joint interval was used in the cases of the winter and the summer cokriged maps.

Summer temperature distribution is homogenous inside the cave (Figure 8.a) as the temperature difference is only $2.63^{\circ} \mathrm{C}$. The lowest temperature was measured in the Flat Hall $\left(8.26^{\circ} \mathrm{C}\right)$, this point is located the lowest (430 $\mathrm{m})$. Meanwhile, the highest temperature was measured in the Giant Hall $\left(10.86^{\circ} \mathrm{C}\right)$, which is located $46 \mathrm{~m}$ higher up. This hall is close to the surface but it is also located the furthest from the entrance (132 m).

The spatial analysis shows very well (Figure 8.b) that the picture of the polynom of the second degree gets closer to the picture of a straight line, which also implies the homogeneity of the data. At the same time, in the north-south direction it is well depicted in the picture of the polynom of the second degree how distance from the entrance influences temperature distribution. In the case of the north-south investigation, all data follow the order of the path already taken. Consequently, the maximum of the function is situated on the surface $\left(19.14^{\circ} \mathrm{C}\right)$, later its tendency is monotonously falling as we follow the Entrance, Housetop route, it reaches its inflexion point in the Flat Hall, from where on it has a monotonously rising tendency up to the Giant Hall.

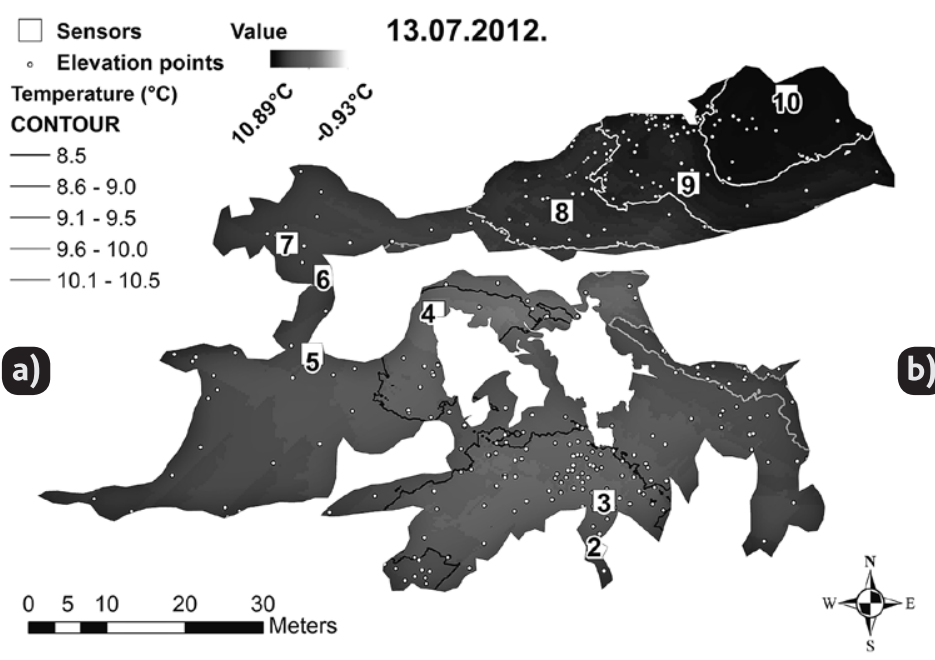

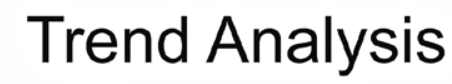

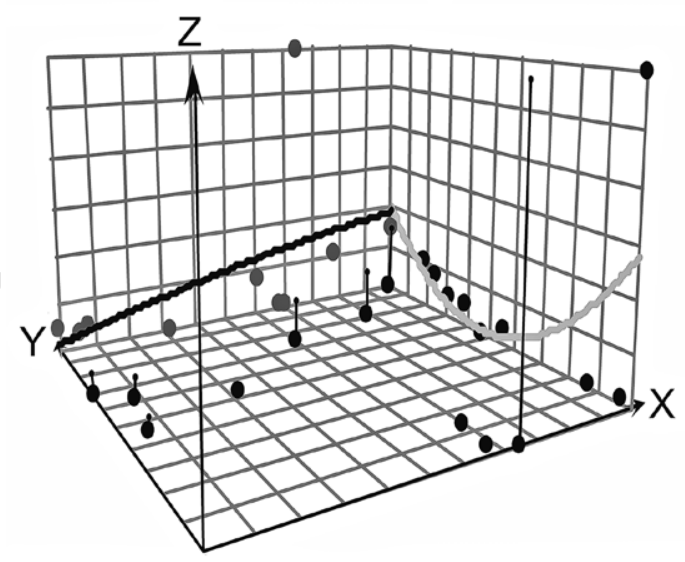

Figure 8. a) Temperature distribution of the summer period (13 July 2012) in the cave, and b) spatial trend analysis of summer data 

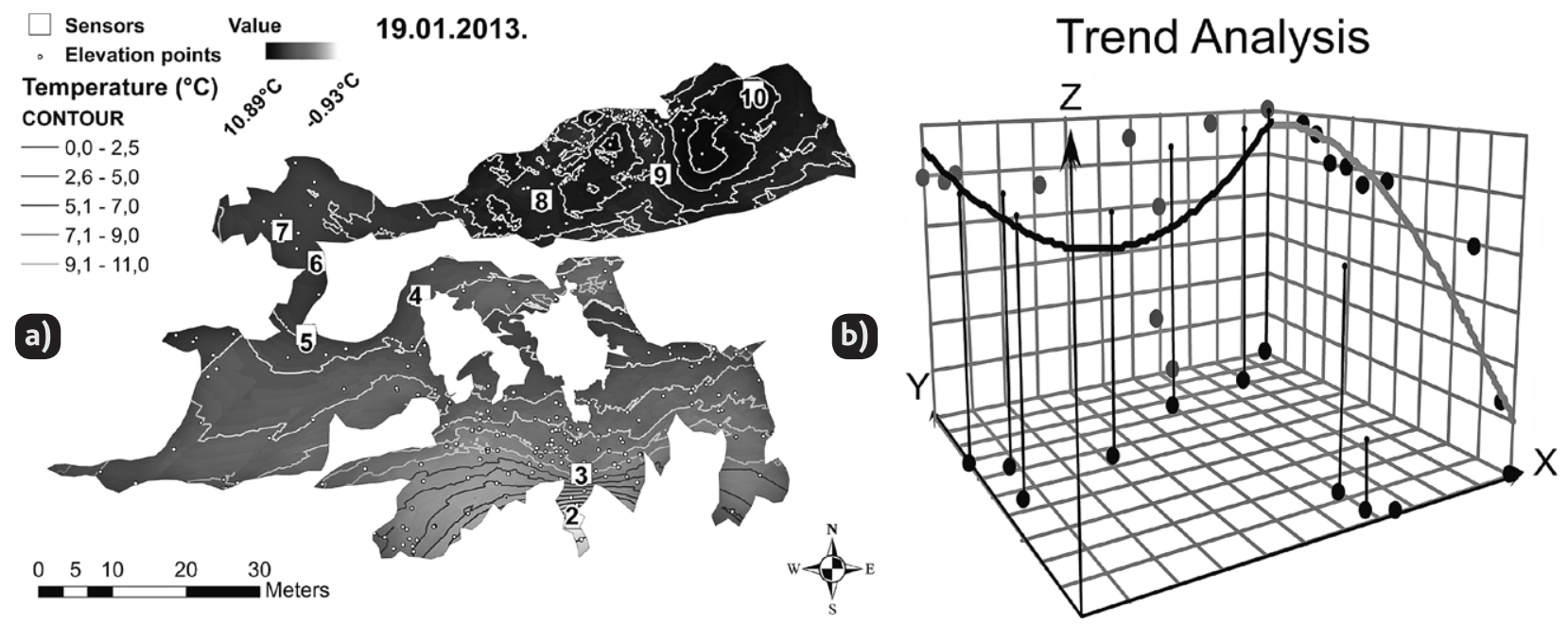

Figure 9. a) Temperature distribution of the winter period (19 January 2013) in the cave, and b) spatial trend analysis of winter data

Winter air circulation makes it much more observable which parts of the cave are affected by the cold thick surface air (Figure 9.a). The average daily surface temperature on the investigated day was $-3.18^{\circ} \mathrm{C}$, which resulted in a $-0.2^{\circ} \mathrm{C}$ average daily temperature value at the entrance. The influence of the cold surface air can be perceived at Housetop $\left(5.94^{\circ} \mathrm{C}\right)$ and the Flat Hall $\left(7.59^{\circ} \mathrm{C}\right)$ as in the summer period the average daily temperature was $1.96^{\circ} \mathrm{C}$ and $0.61^{\circ} \mathrm{C}$ higher at these points respectively.

The spatial analysis also reveals (Figure 9.b) that in the case of east-west distribution of the temperature values of the investigated points, the polynom of the second degree starts at the Almond (7), it has a monotonously falling tendency at the points of investigation between the Great Hall and Leyla, at Leyla (6), the Flat Hall (4), the Gallery (8), the Entrance (2) and the Housetop (2). It reaches the inflexion point on the surface (1), and from there on a monotonously rising tendency is observable between the Gallery and the Giant Hall (9) and at the Giant Hall. When analyzing the north-south direction, the picture of the polynom

a)

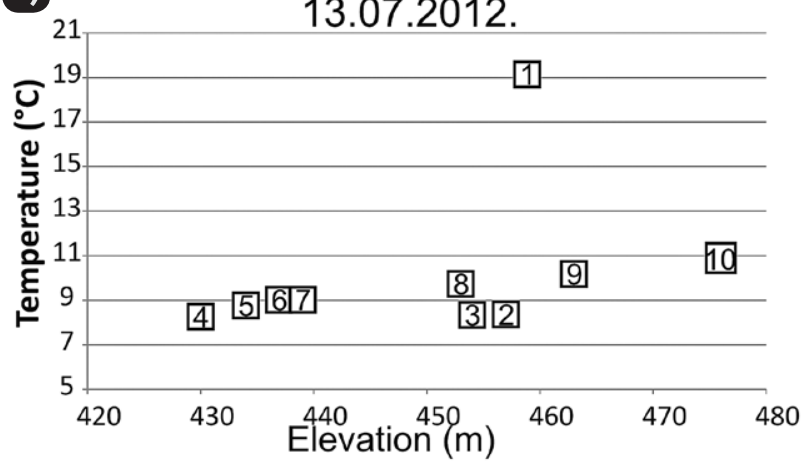

of the second degree rises monotonously up until the Giant Hall (10).

The diagram of the actual vertical distribution of the temperature was created using the data of the previously mentioned two day in the course of the spatial analysis (Figure 10). Temperature data are arranged according to a.s.l. height (Flat Hall (4), between Great Hall and Leyla (5), Leyla (6), Almond (7), Gallery (8), Housetop (3), Entrance (2), Surface, between Gallery and Giant Hall (9), Giant Hall (10)).

The vertical distribution of summer temperature values also indicates the homogeneity of the cave temperature (Figure 10.a). The lowest average daily temperature $\left(8.20^{\circ} \mathrm{C}\right)$ that day was recorded in the Flat Hall, temperature then gradually rises up to the Giant Hall $\left(10.89^{\circ} \mathrm{C}\right)$. Although the average daily temperature on the surface was $19^{\circ} \mathrm{C}$, the Housetop and the Entrance parts had $1.3^{\circ} \mathrm{C}$ lower temperature compared to the relief location, which was due to the intensity of the air flowing outside from the cave.

The same vertical lamination can be found in the investigated cave part when there is winter air circu-

Figure 10. Vertical temperature distribution as a function of a.s.l. height a) summer data (13 July 2012), b) winter data (09 January 2013)

b)

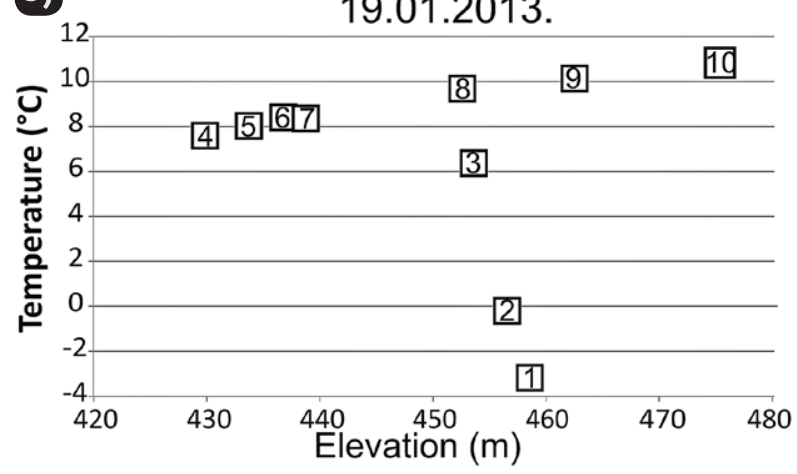


lation, the difference is that air temperature is layered only between $7.59-10.83^{\circ} \mathrm{C}$ (Figure 10.b). The $-3.1^{\circ} \mathrm{C}$ average temperature of the entrance zone affects more distinguishable changes to happen; temperature is $8.5^{\circ} \mathrm{C}$ lower at the Entrance (2), and $2^{\circ} \mathrm{C}$ lower at the Housetop (3) at the given a.s.l. height.

\section{Conclusion}

Temperature observation data were collected in Hajnóczy Cave in order to characterize the microclimate of a temperate zone cave system in summer as well as in winter conditions. The applied wireless sensor system operated well.

We were able to observe how surface air influences the air circulation of the cave in a one-year long period. The daily average temperature on the surface varied between $-6-+29^{\circ} \mathrm{C}$ in the research period. The cave can be divided into three parts on the basis of influences modifying the air circulation of the cave. The first part is the entrance zone where the cave air is heavily affected by the surface air temperature (Entrance (2), Housetop (3)). The second part already exhibits the daily fluctuation of the surface as well as the changing of the seasons. These points of investigation have narrow cross sectional shape, but they are situated at least $47 \mathrm{~m}$ further from the entrance (Flat Hall (4), between Great Hall and Leyla (5), Leyla (6), Almond (7)). The third part shows $0.25^{\circ} \mathrm{C}$ changes on average, they are situated spatially $100 \mathrm{~m}$ further away from the entrance (Gallery ( 7 ), between Gallery and Giant Hall (8), Giant Hall (10)). As the crevices of the Giant Hall let surface air in, its temperature change is synchronized with surface air temperature changes.

We were also able to observe that a change in the air circulation is induced by a permanently below $10^{\circ} \mathrm{C}$ daily temperature. This phenomenon started on 27 th November 2012 in the investigated time period, and the steady cooling of the surface environment exerted greater and greater influence over the air of the cave.

By employing the method of cokriging, we prepared the maps of a summer and a winter spatial temperature distribution. The Giant Hall is depicted the warmest as well as the driest place of the cave. The whole southern wall of the hall exhibits a large dripstone flow called "Winter Forest", but there is not enough dripping water in the Hall due to its being the warmest and the driest. As a result, the erosion of the dripstone formations is present.

\section{Acknowledgements}

The instruments were provided by the TÁMOP-4.2.2/08/1/2008-0008 program of the Hungarian National Development Agency.
We would like to express our appreciation to all those who contributed to our work. Special thanks goes to Dr. Miklós Maróti, Zoltán Csépe, Csaba Varga, Ākos Mező and Károly Barta for their help. We would like to thank Anett Kádár for the translation.

\section{References}

Abuoufirassi, M., Marino, M.A. 1984. Cokriging of Aquifer Trensmissivities from Field Measurements of Transmissivity. Mathematical Geology 16, 19-35.

Badino, G. 2004. Cave Temperature and global climatic changes. International Journal of Speleology 33, 103-114.

Bárány-Kevei, I., Mucsi, L. 1995. Acidification and other karst soil processes in Hungary. Acta Carsologica 24, 71-82.

Cigna, A.A. 2002. Modern trend in cave monitoring. Acta Carstologica 31, 35-54.

Dezső, Z., Molnár, L. 2001. Cave Climate and radon connections. Professional of Cave Research Meeting, Esztergom, 1-8. (in Hungarian)

Fodor, I. 1980. The mathematical-statistical analysis of the climatic conditions of the speleotheraphy 13-16. 9. 1979. in Ennepetal, 44-52. (in German)

Fodor, I. 1981. The climatic and bioclimatological characteristics of the caves,. Akadémia Press, Budapest, $190 \mathrm{pp}$.

Hakl, J., Hunyadi, I., Csige, I., Géczy, G., Lénárt, L., Várhegyi, A. 1997. Radon transport phenomena studied in karst caves - International experiences on radon levels and exposures. Radiation Measurements 28, 675-684.

Hevesi, A. 1978. Structure and surface evolution of the Bükk Mountains. Földrajzi Értesitö. Geographical Bulletin 27, 169-209. (in Hungarian with English summary)

Hevesi, A. 2002. About the development of limestone Gorge. Acta geographica Croatia 35, 57-66.

Hir, J. 1985. Hajnóczy Cave sediments. Karst and Cave (Karszt és Barlang), 21-40. (in Hungarian with English summary)

Horváth, T. 1984. The cave therapy as a method of rehabilitation respiratory effects of airway obstruction. Balneologic, Rehabilitation, Spa case 5, 167. (in Hungarian)

Jakucs, L. 1977. Morphogenetics of karst regions: variants of karst evolution. Akadémia Press, Budapest, $310 \mathrm{pp}$.

Johnson, K., Ver Hoef, J.M., Krivoruchko, K., Lucas, N. 2003. ArcGIS9: Using ArcGIS Geostatistical Analysis. <http://dusk.geo.orst.edu/gis/geostat_ analyst.pdf $>$

Kaffai, O., Imecs, Z. 2008.F Mikroclimatological measurements in the Zichy Cave on Körösrév. 
Karst Development (Karsztfejlödés) 13, 269-277. (in Hungarian with English summary)

Kessler, H. 1942. The depths of caves. Franklin Press, Budapest, $151 \mathrm{pp}$.

Kordos, L. 1984. Hungarian caves. Gondolat Press, Budapest, 315 pp. (in Hungarian)

Leél-Össy, Sz., Surányi, G. 2003 The peculiar hydrothermal caves in Budapest (Hungary). Acta Geologica Hungarica 46, 407-436.

Miklós, G. 1978. The mikroclimate of the Hajnóczy Cave. Karst and Cave (Karszt és Barlang), 11-18. (in Hungarian with English summary)

Mucsi, L. 1989. Connection between different soiltypes and seeping water system in the cave-Hajnóczy, X. International Conference of Speleology Nemzetközi Barlangtani Konferencia, 226-228.

Mucsi, L. 1992. Investigation of karst morphology in Odorvar, Specific reference to difference surface rocks. Szeged, 94 pp. (in Hungarian)

Mucsi, L., Balog, A., Juhász G. 2004. Interactive 3D cave system information on the web. Geodesy and Cartography 56, 3-8. (in Hungarian)

Mucsi, L., Muladi, B., Henits, L., Farsang, A., Albrect, V. 2014. Large Scale UHI Mapping Based on Spatial Information Provided by Young Volunteers. Carpathian Journal of Earth and Environmental Sciences 9, $31-43$.

Muladi, B., Csépe, Z., Mucsi, L., Puskás, I., Koltai, G., Bauer, M. 2013. Climatic features of different karst caves in Hungary In: Michal Filippi, Pavel Bosák (szerk.) 16th International Congress of Speleology: Proceedings Volume 2 Prague: Czech Speleological Society, 432-438.

Muladi, B., Mucsi, L. 2014. Investigation of daly natural and rapid human effects on the air. Journal of Environmental Geography 6, 21-29.
Németh, G. 1964. Observations of Odorvár - Manuscript from the data warehouse of the Tiszazug Geographical museum 1547/1965. lt. sz. alatt. 1-13. (in Hungarian)

Ogimet, Meteorological data from Eger http://www. ogimet.com/synops.phtml

Rajczy, M. 2000. Climatological measurements IN Börcsök P.(szerk.) Informations for cave research leaders Budapest, 137-139. (in Hungarian)

Somogyi, Gy., Varga, Zs., Németh, Gy., Pálfalvi, J., Gerzson, I. 1983. Radon measurement int he Hajnóczy Cave. Isotope technique 26, 38. (in Hungarian)

Tobin, B. W., Hutchins, B. T., Schwartz, B. F. 2013. Spatial and temporal changes in invertebrate assemblage structure from the entrance to deepcave zone of a temperate marble cave. International Journal of Speleology 42, 203-214.

Varga Cs. 1978. Hajnóczy Cave on Odorvár. Karst and Cave (Karszt és Barlang), I-II. p. 7-10. (in Hungarian with English summary)

Varga, Cs. 2003. Hajnóczy Cave In Székely, K. (ed.) Highly protected caves in Hungary Mezőgazda Press, Budapest, 200-204. (in Hungarian)

Varga, L. 1970. Data from the Odor-vár and surrounding karst morphology. Geographical Bulletin Földrajzi Értesitő 19, 95-107. (in Hungarian with German summary)

Veress, M. 2009. Investigation of covered karst form development using geophysical measurements. Zeitschrift für Geomorphologie 53, 469-486.

Zámbó L. 1993. Influence of soil impact on karst corrosion. Conference. on the Karst and Cave Research Activities of. Ed. and Research Inst. in Hungary. Jósvafõ. 147-154. 